\title{
Unit per Gram per Day
}

National Cancer Institute

\section{Source}

National Cancer Institute. Unit per Gram per Day. NCI Thesaurus. Code C73774.

An arbitrary unit of substance rate expressed in unit(s) per gram per period of time equal to twenty-four hours. 